\title{
Observations of heterogeneous pore pressure distributions in clay-rich materials
}

Robert Cuss, Jon Harrington, Caroline Graham, Shanvas Sathar, and Tony

Milodowski

British Geological Survey, Keyworth, Nottingham, NG12 5GG, UK

01159363486

ricu@bgs.ac.uk

\begin{abstract}
The concept of effective stress is one of the basic tenets of rock mechanics where the stress acting on a rock can be viewed as the total stress minus the pore water pressure. In many materials, including clay-rich rocks, this relationship has been seen to be imperfect and a coefficient $(\chi)$ is added to account for the mechanical properties of the clay matrix. Recent experimental results seen during the flow testing (both gas and water) of several rocks (Callovo-Oxfordian claystone, Opalinus Clay, Boom Clay) and geomaterials (bentonite, kaolinite) has given evidence for stable high pressure differentials. The design of experimental setups gives multiple measurements of pore pressure, often showing a complex distribution for several different experimental geometries. The observed stable high pressure differentials and heterogeneous pore pressure distribution makes the describing of stress states in terms of effective stress complex. Highly localised pore pressures can be sustained by argillaceous materials and concepts of evenly distributed pore pressures throughout the sample, i.e. conventional effective stress, do not fit many clay-rich rocks if the complexities observed on the micro-scale are not incorporated, especially when considering the case of gaseous flow.
\end{abstract}




\section{Introduction}

The introduction of pore-fluid under pressure has a profound effect on the physical properties of porous solids (Hubbert and Rubey, 1961; Terzaghi, 1943). In a saturated porous system, the fluid supports some proportion of the applied load, creating fluidpressure, which acts in the opposite direction to load, lowering the overall stress exerted through grains. The addition of fluid pressure lowers available stress by an amount that is proportional to the pore pressure. Therefore the law of effective stress states:

$$
\sigma^{\prime}=\sigma-u
$$

where $\sigma^{\prime}$ is effective stress, $\sigma$ is total stress, and $u$ is pore pressure. Strength is determined not by confining pressure alone, but by the difference between confining and pore-pressures. In simple drained tests, pore pressure remains constant at atmospheric pressure and the observed effective stress is similar to the applied load. Conversely, if the pore-fluid system is closed, pore pressure rises in proportion to the applied load as pore space is reduced, significantly lowering the overall effective stress. Thus, the mechanical response of rocks to applied load is significantly affected by the ability of fluids to drain.

Many rocks have been shown to follow the law of effective stress, including shale (Handin et al., 1963; Kwon et al., 2001) and sandstone (Byerlee, 1975; Cuss, 1999). However, due to the compressibility of clay and the poroelastic effect (after Biot, 1941), where the effective stress is modified by the partial transfer of pore-pressure to the granular framework, the law of effective stress is modified with the effective pressure coefficient $(\chi)$ :

$$
\sigma^{\prime}=\sigma-\chi u
$$


Kwon et al. (2001) showed that the effective pressure coefficient $\chi$ was equal to 0.99 \pm 0.06 for Wilcox shale. This value is indistinguishable from unity and demonstrates that the law of effective stress is obeyed in this particular shale variety. Burrus (1998) showed that $\chi$ much less than unity was appropriate for shale for the Mahakam Delta $(\chi=0.65-0.85)$.

Conceptual models of argillaceous rock deformation, such as critical state soil mechanics (Schofield and Wroth, 1968; Atkinson and Bransby, 1978; Wood, 1990), use the law of effective stress. Therefore careful experimentation has to be undertaken to account for drainage effects and to determine the role that pore pressure has on the deformation of sediments. This paper gives examples of observations of pore pressure in a number of experimental studies, which make the defining of effective stress difficult in low permeability argillaceous materials.

In recent years the British Geological Survey (BGS) has undertaken a number of fluid transport experimental studies using isotropic, triaxial, shear and full-scale demonstration testing configurations. This paper draws together a number of observations of pore pressure heterogeneity for various argillaceous materials. These localised heterogeneities give rise to additional complication of the law of effective stress and may be resultant of the mechanisms of fluid flow. Table 1 summarises the experimental boundary conditions of the different test geometries and the basic physical properties of the test materials.

\section{Experimental geometry 1 - Triaxial testing}

The Stress-Path Permeameter (SPP, Figure 1) was used to investigate water and gas (helium) flow in Callovo-Oxfordian claystone from the Bure Underground Research Laboratory (URL) in the eastern part of the Paris Basin under in situ conditions (see 
Table 1 for test material parameters and experimental boundary conditions). The triaxial SPP testing rig was designed to observe sample volume changes during flow experiments conducted along an evolving stress-path; please note that the results presented here were for a static triaxial boundary condition. The apparatus had a thick-walled pressure vessel which imposed a confining pressure (12.5 MPa) through the compression of glycerol by an ISCO syringe pump. The testing sample was cylindrical and of $56 \mathrm{~mm}$ diameter and $82 \mathrm{~mm}$ length. The sample was jacketed in a Hoek-sleeve, which had been thinned to reduce compressibility and had three brassplates cemented to the outside of the jacket. Three pressure-balanced devices (dashpots) allowed direct measurement of the displacement of these plates to give radial displacement. The sample was axially loaded by an Enerpac hydraulic ram driven by an ISCO syringe pump, giving a stress of $13 \mathrm{MPa}$ in the axial direction. Axial displacement was directly recorded by a Mitutoyo digital micrometer. The porepressure system had two ISCO syringe pumps; one acted as an injection pump and the other maintained constant back-pressure (4.5 MPa). A test was conducted using stages of constant pressure or constant-flow pressure ramps in the injection system in order to initiate gas or water flow. The experimental rig was completed by a number of pressure sensors, thermocouples and a digital acquisition system, which logged data every 2 minutes.

One experimental uncertainty in transport testing is the short-circuiting of the flow system along the jacket of the test sample. The addition of a $6 \mathrm{~mm}$ wide, $2 \mathrm{~mm}$ deep, porous stainless-steel annular filter along the outer edge of each platen (Figure 1b) allowed pore-water pressure to be monitored and discount unwanted sidewall flow. The inlet/outlet filter was made up of a porous disc $20 \mathrm{~mm}$ in diameter and $2 \mathrm{~mm}$ depth. The two guard-rings were each connected to a pressure transducer and the 
complete guard-ring system (filter, pipework and pressure sensor) was saturated with water and flushed in order to eliminate gas from the system. The control board of the apparatus allowed the guard rings to be either connected to the injection system to assist in hydration, or isolated to give an independent measure of pore-pressure. As well as being able to eliminate side-wall flow as a possible transport mechanism, the guard rings meant pore pressure was measured at four different points on the test sample (injection pressure, injection guard-ring pressure, back pressure, back guardring pressure) providing data on the hydraulic anisotropy and symmetry within the sample.

The SPP was used to conduct experiments on the Callovo-Oxfordian claystone (COx) under in situ stress conditions. Wenk et al. (2008) reports clay $25-55 \mathrm{wt} \%, 23-44 \%$ carbonates and 20-31\% silt (essentially quartz + feldspar). Clay minerals are reported to include illite and illite-smectite with subordinate kaolinite and chlorite. The test sample was prepared by dry machine lathing and the ends were ground flat and parallel giving an $82.45 \mathrm{~mm}$ length sample. The starting water saturation of the sample was $96 \%$, with the early stages of testing designed to raise this to full saturation. Table 1 summarises the geotechnical properties of the starting material, on completion of the full test programme the sample was seen to have saturation close to $100 \%$.

\section{Observed pore pressure distribution under in situ stress conditions}

The first stage of testing imposed stress conditions similar to the in situ conditions for the borehole the test sample was taken from $\left(\sigma_{1}=13 \mathrm{MPa}, \sigma_{2}=\sigma_{3}=12.5 \mathrm{MPa}, P_{p}=\right.$ 4.5 MPa). Chemically balanced water was injected at both ends of the sample in order to re-establish full sample saturation and to minimise chemically driven swelling of the sample. During extraction, storage and sample preparation the sample will have 
undergone small amounts of desaturation and this stage of the test counteracts this effect. During this initial resaturation stage, the inlet/outlet and guard rings were used to hydrate the sample and ensured that the air content of all pipework and pressure transducers was negligible. Following the initial resaturation stage, a two-step constant head test was conducted, as shown in Figure 2a. At the start of this test stage the injection pore pressure, including the guard ring, was raised to $8.5 \mathrm{MPa}$ and then the guard-rings were isolated. Both injection (IGR) and back-pressure (BGR) guard rings showed an initial decrease in pore-pressure, which within a couple of days started to recover in pressure and equilibrated. The IGR stabilised approximately 1 MPa below the injection pressure, whereas BGR was about $0.5 \mathrm{MPa}$ above the back pressure.

Injection pore pressure was lowered to $4.5 \mathrm{MPa}$ on Day 98. Over the subsequent remaining 32 days of the low pressure constant head hydraulic test stage a slow decrease in pore pressure in IGR and BGR was seen, with BGR decreasing much slower than IGR.

The data show that a relatively even distribution in pore pressure is created in the sample due to the high pressure imposed at the injection end of the sample. This suggests a relatively evenly distributed pore pressure gradient through the sample. The difference in pore pressure over a relatively small distance suggests a high pressure gradient of approximately $100 \mathrm{MPa} / \mathrm{m}$, which resulted in a flow of only $2.8 \times 10^{-13} \mathrm{~m}^{3} \cdot \mathrm{s}^{-1}$.

Following the hydraulic head test, a helium gas injection test was conducted. As shown in Figure 2b, the response of the guard rings is much more complicated during gas testing. The onset of gas flow was higher than anticipated and hence the need for the slow careful raising of gas pressure at the injection inlet. Gas pressure was raised 
by means of a constant flow pressure-ramp to raise pressure to $9.5 \mathrm{MPa}$ over 30 days. Pressure was then held constant, before a series of pressure ramps slowly increased gas pressure by $0.5 \mathrm{MPa}$ each step.

Figure $2 \mathrm{~b}$ shows that BGR pressure showed little pressure change during the first pressure ramp, whilst IGR pressure showed a small increase. Prior to the switch to constant pressure the guard ring pressure data showed an increase; IGR pressure peaked at $\sim 5.2 \mathrm{MPa}$ and slowly decayed. This corresponded with no change of inflow into, or outflow from, the sample. Up until approximately Day 237, the pressure within the guard rings appeared to be independent of the injection gas pressure. This showed that within the test sample very little pore pressure change had occurred and gas had not started to enter the sample. Even accounting for the differences in compressibility of helium and water, the "bulk" sample pore pressure was relatively unaffected by the injection pressure.

The final pressure ramp was initiated on Day 236 and raised pore pressure by $0.5 \mathrm{MPa}$ over a 3 week period; pressure in IGR started to increase from Day 236 onwards. It is difficult to determine precisely when BGR pressure started to increase, however there was a lag of approximately one day compared with IGR. Between Day 237 and Day 254.7 the pressure in IGR increased from 4.6 $\mathrm{MPa}$ to $6.3 \mathrm{MPa}$, whilst in BGR pressure increased from 4.5 MPa to 4.9 $\mathrm{MPa}$. At Day 254.7 pressure in IGR increased significantly and rapidly from $6.3 \mathrm{MPa}$ to a peak of $10.5 \mathrm{MPa}$.

The observed pore pressure response showed that little change occured prior to the onset of gas flow into the sample. Once this occurs there is a considerable difference in pore pressure within the sample. Pore pressure is not as evenly distributed throughout the sample as was seen during the hydraulic head test. The maximum pressure difference observed equates to a gradient of $400 \mathrm{MPa} / \mathrm{m}$. 
The differences between pore pressure response for water and gas flow suggest that the flow mechanisms are different. Harrington et al. (2012) show that at the onset of gas flow Callovo-Oxfordian claystone undergoes volumetric dilation. This suggests that gas flow was along localised dilatant pathways (micro-fissuring) which may or may not interact with the continuum stress field; also termed dilatancy flow. As well as strain data, dilatancy flow in argillaceous materials has also been suggested from studies of nano-particle invasion in Boom Clay (Harrington et al., 2012) and during the heating of Opalinus Clay in glycerol (Harrington et al., 2003), which suggested that gas flow in this material was through a small number of discrete pathways. All of these observations suggest that water flow at elevated pore pressures results in pervasive changes in pore pressure, whereas gas flow at elevated pressures has a much more localised influence. This suggests that an effective stress law may usefully be applied to the case of water as a pore fluid, but may only be applicable on a local scale for gas flow.

\section{Experimental geometry 2 - interface testing}

The Angled Shear Rig (ASR, Figure 3a) was used to investigate water and gas flow within a kaolinite gouge sandwiched between two steel platens angled to the stressfield (see Table 1 for test material parameters and experimental boundary conditions). Kaolinite pastes were prepared and placed between two polished steel blocks, which maintained a $60 \mathrm{~mm} \times 60 \mathrm{~mm}$ contact area. The apparatus was designed with the following specification; normal load of up to $12 \mathrm{MPa}$, injection pore pressure of $0.5-$ $12 \mathrm{MPa}$, vertical displacement measured to a precision greater than $60 \mathrm{~nm}$ using an induction device, "fracture" thickness measured to sub-micron accuracy by an eddy current device, and pore pressure measured at two locations on the slip-plane (see Figure 3a for locations). See Sathar et al. (2012) for a more detailed experimental 
description. The results presented here were not recorded during an active shear experiment, however small shear movements ( $<5$ microns) occur early during the loading history creating a shear stress in the gouge material.

\section{Observed pore pressure distribution during interface testing}

Figure 4 shows the results from two experiments conducted using the ASR apparatus. Figure 4a shows the results from a water injection test (ASR_Tau01), with a constant injection pressure of $0.75 \mathrm{MPa}$, the normal load was increased and decreased in steps from $0.2 \mathrm{MPa}$ to $3 \mathrm{MPa}$ to $0.1 \mathrm{MPa}$. As injection pore pressure was raised to $750 \mathrm{kPa}$, flow initiated and the pore pressure within the slip-plane increased with a timedependent response until reaching a peak of about $24 \mathrm{kPa}$. As normal load was stepped up and down from $2 \mathrm{MPa}$ to $3 \mathrm{MPa}$ to $2 \mathrm{MPa}$ the pore pressure in the slipplane remained relatively unchanged, apart from the initial time-dependent response. One of the slip-plane pore pressure sensors shows a slow decay, whereas the other maintains a constant pressure. After 20 days the pore pressure was allowed to leakoff, the rate of pressure decay was slow due to the low permeability of the compressed kaolinite paste. Leak-off can be seen to have a marked influence on the pore pressure within the slip-plane. Therefore injection pressure was the primary control on pore pressure distribution during water injection testing. It should be noted that the pore pressure in the slip-plane was of the order of $20 \mathrm{kPa}$ with an injection pressure of 750 $\mathrm{kPa}$. This suggests that pore pressure drop-off from the central injection filter was greater than simple radial flow would predict or that flow was localised within the kaolinite. The response of the pore pressure on the slip-plane appears to mainly be due to drainage along the slip- plane and the injection pressure and is not a function of normal load. 
Figure $4 \mathrm{~b}$ shows the result of pore pressure on the slip-plane during gas testing (test ASR_Tau12). In order to initiate flow the gas pressure was slowly increased from 3.5 MPa up to $5 \mathrm{MPa}$. Once flow had been initiated the normal load was stepped up and down from 0.3 MPa to $3 \mathrm{MPa}$ to $0.3 \mathrm{MPa}$. During the full duration of this test (and subsequent gas tests) no response was observed in the pore pressure within the slipplane. This suggests that gas flow was localised and that its impact on pore pressure within the slip-plane was minimal.

\section{Experimental geometry 3 - shear testing}

The Direct Shear Rig (DSR, Figure 3b) was used to investigate fracture transmissivity of Opalinus Clay from the Mont Terri Underground Research Laboratory in the northwest of Switzerland under realistic in situ loading conditions (see Table 1 for test material parameters and experimental boundary conditions). The DSR is similar to the Angled Shear Rig, but is designed to test rock samples. The apparatus was designed with the following specification to test two prepared samples of $60 \mathrm{~mm} \times 60 \mathrm{~mm}$ $\times 21 \mathrm{~mm}$; normal load of up to $12 \mathrm{MPa}$, injection pore pressure of $0.5-12 \mathrm{MPa}$, shear as slow as $1 \mathrm{~mm}$ per 3 month period, and vertical displacement measured to a precision greater than $60 \mathrm{~nm}$. Pore pressure can be injected directly to the fracture plane by means of a $4 \mathrm{~mm}$ diameter injection pipe (See Cuss et al., $2011^{\mathrm{b}}$ for a more detailed description).

Opalinus Clay has the following composition; clay-mineral content ranges from 40 80 wt $\%(9-29 \%$ illite, $3-10 \%$ chlorite, $6-20 \%$ kaolinite, and $4-12 \%$ illite/smectite mixed layers in the ratio 70/30). Other minerals are quartz $(15-30 \%)$, calcite $(6-40 \%)$, siderite $(2-3 \%)$, ankerite $(0-3 \%)$, feldspars $(1-7 \%)$, pyrite $(1-3 \%)$, and organic carbon $(<1 \%)$. The total water content ranges from $4-19 \mathrm{wt}$ 
$\%$ (Gautschi, 2001). Table 1 summarises the geotechnical properties of the starting material.

\section{Observed pore water distribution during shear testing}

Figure 5 shows the results from water injection test DSR_OPA-1 conducted at 1.2 $\mathrm{MPa}$ normal load with an injection pressure of $1 \mathrm{MPa}$ at a shear rate of 85 microns/day. Cuss et al. $\left(2011^{\mathrm{b}}\right)$ describes the full test history in detail. Late in the test history after nearly $6 \mathrm{~mm}$ of shear had occurred, fluorescein was added to the injection fluid to allow imaging of the distribution of flow along the fracture plane. As shown in Figure 5, even during water transport along a confined planar interface, flow was highly variable and far from perfectly radial. Flow preferentially followed microscale fractures that formed in the fracture surface. Water flow paths are seen to be complex and only about a quarter of the fracture plane contributed to overall flow.

\section{Experimental geometry 4 - Full scale demonstration (Lasgit)}

The on-going Large scale gas injection test (Lasgit) is a full-scale experiment based on the Swedish KBS-3V repository concept, examining the processes controlling gas and water flow in compact buffer bentonite (see Cuss et al., 2010). The experiment was commissioned in a $9 \mathrm{~m}$ deep, $1.75 \mathrm{~m}$ diameter deposition hole at $420 \mathrm{~m}$ depth within the Äspö Hard Rock Laboratory (HRL) in Sweden. The experiment aimed to perform and interpret a series of gas injection tests in a full-scale mock-up of the KBS-3V disposal concept. Issues relating to up-scaling were examined and its effect on gas movement and buffer performance. The test data allowed processes governing gas migration to be investigated and allowed testing/validation of modelling approaches aimed at repository performance assessment. 
A full-scale KBS-3 canister (see Figure 6 for schematic) was modified with thirteen circular filters of varying dimensions located on its surface to simulate potential canister defects. These filters could also be used to inject water during hydration stages to help locally saturate the buffer around each test filter. The canister was surrounded by specially manufactured pre-compacted bentonite blocks, all of which had initial water saturations in excess of $95 \%$ (see Table 1 for test material parameters and experimental boundary conditions). The deposition hole, buffer and canister were equipped with instrumentation to measure the total stress, pore-water pressure and relative humidity in 32, 26 and 7 positions respectively (see Figure 6 for the location of pore-water sensors). Additional instrumentation continually monitored variations in temperature, relative displacement of the lid \& canister, and the restraining forces on the rock anchors. The emplacement hole had been capped by a conical concrete plug retained by a reinforced carbon steel lid. The experiment was monitored and controlled from a temperature controlled "Gas Laboratory" that allowed remote control and monitoring of the test to be undertaken by project staff remotely.

\section{Observed pore pressure distribution in full-scale testing}

The size of Lasgit has allowed pore pressure to be monitored at 50 locations for in excess of 6.5 years. Figure 7 shows the results for a number of pore pressure sensors during the full history of the experiment. Following initial hydration pore pressure at the rock wall (UR sensors, Figure 7a, Figure 6) increased to between 1,250 and $2,700 \mathrm{kPa}$ and since reaching a maximum about Day 600, UR sensors have generally decreased, on average at a rate of approximately $40 \mathrm{kPa}$ per year. This is thought to be due to the change in drawdown of the main tunnel of the Äspö HRL.

Pore-water pressure within the bentonite blocks (UB sensors, Figure 7b, Figure 6) had a much more complex history. Generally pore pressure remains low at $220-750 \mathrm{kPa}$, 
except for UB902, which was pressured during the second gas injection test when gas reached this location. The pore pressure history was complex with periods of pressure increase and decrease, with some evidence of seasonal variation. However, the seasonal variation was non-uniform and non-repeatable in some sensors.

While the test had been continually hydrated at $2.5 \mathrm{MPa}$, pore pressure distribution within the deposition hole remains complex ranging from 220 to $2,500 \mathrm{kPa}$. While the bentonite continues to mature, hydraulic constant head tests at various times in the test history and psychrometer data from seven locations within the bentonite show that the buffer is in hydraulic disequilibrium. Even taking this into account the distribution of hydraulic pore pressure is complex on the full-scale.

Figure 8 shows the observed pore pressure during the second gas injection test (see Cuss et al., 2011 ${ }^{\text {a }}$ for more detail). Gas pressure was increased in one canister filter (FL903, section 5 Figure 6) from 2.5 to approximately $6 \mathrm{MPa}$. During this pressurisation no other filter showed a change in pore pressure. At gas breakthrough at Day 1769.7 when gas flow was initiated, none of the lower canister filters showed a change in pore pressure, whereas only 6 pore pressure sensors on the rock wall (UR sensor) showed any variation. The maximum disturbance seen in the UR sensors was an increase of $\sim 50 \mathrm{kPa}$ and this was likely to be a hydro-mechanical response.

Examination of pore pressure sensor data indicates that gas migrated temporally within the system to different locations. As seen in Figure 8a, pore pressure in filter FL901 started to increase in a series of steps initiating at Day 1772.9, some 3.2 days after gas breakthrough. Pore pressure greatly increased in sensor UB902 (Figure 8b) within the bentonite at Day 1785.4, some 15.7 days after gas breakthrough. For both of these events no significant change in pore pressure is observed elsewhere in the system suggesting that gas migrated directly to these sinks. These observations show 
that gas flow was localised within the Lasgit deposition hole and that pore pressure was not evenly distributed throughout the deposition hole.

\section{Discussion and implications}

The mechanical deformation of argillaceous rocks is usually described in terms of effective stress, which is one of the basic tenets of rock mechanics. In order to do this it is important accurately to describe pore pressure. In this paper we have shown that pore pressure distribution during different laboratory and full-scale experiments was far from simple during both water and gas injection testing. This complexity, even taking into account anisotropy and material heterogeneities, is not easily described by a single value of $\chi$ in the law of effective stress as we cannot answer the simple question "what is the pore pressure of the bulk sample?"

Laboratory triaxial experiments suggest that hydraulic pore pressure can be described as an evenly distributed quantity that is dictated by the boundary conditions of the experiment. However, the pore pressure distribution observed in shear experiments and in the full-scale Lasgit test suggest that pore pressures are not evenly distributed and can be localised into almost isolated areas, although in the case of Lasgit this may stem from disequilibrium. This is most obvious in the shear experimental results where only approximately a quarter of the fracture surface is contributing to the flow of water. Observations within Lasgit show that pore pressure is very heterogeneous, with high pore pressures seen at the rock wall and low pressures seen within the bentonite. Constant head testing has no observable effect on other pore pressure sensors and suggests that pore pressure variation is localised to a relatively small zone around the injection filter. 
The localisation of pore pressure variation in Lasgit may be explained by the mechanical compressibility of the bentonite buffer and its low permeability. The matrix of the buffer was able to accommodate the displaced pore water by compression, whereas on the sample scale in the laboratory the pressure differences are seen to be explainable by even distribution of pore pressure within the pore network. However, this cannot explain the non-radial flow seen in shear-box testing.

The observations of pore pressure variation during gas injection show that gas transport mechanisms are dissimilar to water flow. Pore pressure observations consistently show localised increases in pore pressure with gas flow along a number of potentially isolated dilatant pathways (micro-fissures). These observations suggest that under these circumstances a meaningful average pore pressure could be difficult to define. Gas pressure within the micro-fissure pathway can be much greater than the pore pressure in the clay surrounding the pathway. A certain amount of pore pressure increase and pore water displacement will occur close to the pathway as a combination of dilation, which will result in localised compression of the clay material, increasing pore pressure through compression of the micro-fissure wall, and the transmission of gas pressure directly through the pathway wall due to the loss of capillary pressure. The driving force of micro-fissure propagation is the gas pressure at the tip of the dilatant feature, which is much greater than the "bulk" pore pressure of the sample. As seen in Lasgit, the majority of the system sees no change in pore pressure as gas pressure increases in an injection filter and even when gas becomes mobile and enters the buffer the pore pressure in the greater part of the system does not vary. Individual sensor responses in triaxial and full-scale testing show that argillaceous materials see no change in pore pressure until gas migrates near to that location and that pressure build-up is then seen to develop quickly. 
Consistent behaviour is observed in a range of argillaceous materials for different experimental geometries; including isotropic (Boom Clay), triaxial (CallovoOxfordian claystone), interface (kaolinite), shear (Opalinus Clay) and full-scale testing (bentonite). This suggests a commonality of behaviour independent of experimental setup and a common underlying physical mechanism involved in gas and water flow. Only relatively minor differences are observed between argillaceous materials, which may be explained by differences in material properties and state of induration. In all of these argillaceous materials it is difficult to determine a bulk pore pressure and thus the use of the law of effective stress may introduce an error into model predictions unless the complexities observed at a micro-scale are incorporated.

The experimental observations are problematic for existing theoretical frameworks, which generally assume homogeneous distributions of pore-pressure. Many of the observed experimental features suggest highly localised increases in pore pressure and a heterogeneous pore pressure distribution. These observations support the hypothesis of dilatancy flow along micro-fissures being the dominant physical mechanism controlling gas flow. Although not described fully in this paper, Harrington et al. (2012) give further evidence of dilatancy flow. Therefore on a micro scale the law of effective stress will describe the deformation of the clay matrix, but on a bulk scale care has to be taken as the "bulk" pore pressure may vary considerably depending on the number, geometry and distribution of gas pathways.

It is important to investigate the controls on gas migration and what controls the formation of dilatant pathways from the micro, macro and field scales. These observations then need to be considered in the development of theoretical frameworks describing stress in such systems.

\section{Conclusions}


Large, stable pressure differentials and gradients were observed in several argillaceous materials during water and gas injection testing for a number of experimental geometries, including isotropic (Boom Clay), triaxial (CallovoOxfordian claystone), shear (kaolinite and Opalinus Clay) and full-scale testing (bentonite). Pore-pressure during water injection appeared to be evenly distributed on the sample scale, whereas in full-scale demonstration a complex distribution was seen, which may partly be due to hydraulic disequilibrium. During gas injection testing all observations suggest that transport was predominantly by dilatancy flow and the formation of micro-fissures. This led to localised pore pressure variations and a complex temporally and spatially varying pore pressure distribution. Isolated pockets of increased gas pressure could be seen to be stable.

The nature of pore-pressure distribution, both hydraulic and gaseous, and the stability of pore pressure differentials means that the description of a meaningful average pore pressure was difficult and thus the use of effective stress with a single $\chi$ value might misrepresent local stresses within the sample. Localised deformation in the formation of dilatant pathways was dominated by the local gas pressure and not the bulk pore pressure. Therefore the law of effective stress on the micro-scale will be valid, whereas on a bulk scale could lead to errors in model predictions.

\section{Acknowledgements}

This study was undertaken by staff from the British Geological Survey (Radioactive Waste Team) and is published with the permission of the Executive Director, British Geological Survey (NERC). Some of the research leading to these results has received funding from the European Atomic Energy Community's Seventh Framework Programme (FP7/2007-2011) under Grant Agreement no230357, the FORGE project. The authors gratefully acknowledge the co-funding of this research by Andra 
(France), Nagra (Switzerland), Nuclear Decommissioning Authority - Radioactive

Waste Management Division (UK), SCK-CEN (Belgium), and SKB (Sweden).

\section{References}

Atkinson, J.H. and Bransby, P.L. (1978) The Mechanics of Soils: An Introduction to Critical State Soil Mechanics. McGraw-Hill, New York.

Biot, M.A. (1941) General theory of three-dimensional consolidation. Journal of Applied Physics, 12, pp. 155-164.

Burrus, J. (1998) Overpressure models for clastic rocks, their relation to hydrocarbon expulsion: A critical re-evaluation, in B. E. Law, G. F. Ulmishek, and V. I. Slavin, eds., Abnormal pressures in hydrocarbon environments: AAPG Memoir 70, p. 3563.

Byerlee, J.D. (1975) The Fracture Strength and Frictional Strength of Weber Sandstone. International Journal of Rock Mechanics and Mining Sciences, 12, pp. $1-4$.

Cuss, R.J., Harrington, J.F., and Noy, D.J. (2010) Large scale gas injection test (Lasgit) performed at the Äspö Hard Rock Laboratory. Summary report 2008. Svensk Kärnbränslehantering AB (SKB) Technical Report TR-10-38, SKB, Stockholm, Sweden. Pp.109.

Cuss, R.J., Harrington, J.F., Noy, D.J., Wikman, A., and Sellin, P (2011 ${ }^{\mathrm{a}}$ ) Large scale gas injection test (Lasgit): Results from two gas injection tests. Physics and Chemistry of the Earth, 36, pp.1729-1742.

Cuss, R.J., Milodowski, A., and Harrington, J.F. (2011 ${ }^{\mathrm{b}}$ ) Fracture transmissivity as a function of normal and shear stress: first results in Opalinus clay. Physics and Chemistry of the Earth, 36, pp.1960-1971.

Cuss, R.J. (1999) An experimental investigation of the mechanical behaviour of sandstones with reference to borehole stability. Ph.D. thesis, Manchester, UK, University of Manchester.

Gautschi, A. (2001) Hydrogeology of a fractured shale (Opalinus Clay): Implications for deep geological disposal of radioactive wastes. Hydrogeology Journal, 9, pp.97-107.

Handin, J., Hager, R.V., Jr., Friedman, M., and Feather, J.N. (1963) Experimental deformation of sedimentary rocks under confining pressure; pore pressure tests. Bulletin of the American Association of Petroleum Geologists, 47, pp. 717-755.

Harrington, J.F., de La Vaissière, R., Noy, D.J., Cuss, R.J. and Talandier, J. (2012) Gas flow in Callovo-Oxfordian Clay (COx): Results from laboratory and fieldscale measurements. Mineralogical Magazine, This edition.

Harrington, J.F., Horseman, S.T. and Noy, D.J. (2003) Measurements of water and gas flow in Opalinus Clay using a novel guard-ring methodology. British Geological Survey Technical Report CR/03/32, 35 p. 
Hubbert, M.K., and Rubey, W.W. (1959) Role of fluid pressure in mechanics of overthrust faulting: 1 - Mechanics of fluid-filled porous solids and its application to overthrust faulting. Geological Society of America Bulletin, 70, pp. 115-166.

Kwon, O., Kronenberg, A.K., Gangi, A.F., and Johnson, B. (2001) Permeability of Wilcox Shale and its effective pressure law. Journal of Geophysical Research, B, Solid Earth and Planets, 106, pp. 19,339-19,353.

Pearson, F.J., Scholtis, A., Gautschi, A., Baeyens, A., Bradbury, M. and Degueldre, C. (1999): Chemistry of porewater. In: Thury M. and Bossart P. (eds): Mont Terri Rock Laboratory: results of the hydrogeological, geochemical and geotechnical experiments performed in 1996 and 1997. Swiss National Hydrological and Geological Survey, Geological Reports No. 23, Bern.

Sathar, S., Reeves, H.J., Cuss, R.J., and Harrington, J.F. (2012) Critical stress theory applied to repository concepts; the importance of stress tensor and stress history in fracture flow. Mineralogical Magazine, This edition.

Schofield, A., and Wroth, C.P. (1968) Critical State Soil Mechanics. London, McGraw-Hill, 310 pp.

Terzaghi, K. (1943) Theoretical Soil Mechanics. New York, John Wiley.

Wenk, H.-R., Voltolini, M., Mazurek, M., Van Loon, L.R. and Vinsot, A. (2008) Preferred Orientations and Anisotropy in Shales: Callovo-Oxfordian Shale (France) and Opalinus Caly (Switzerland). Clays and Clay Minerals, 56, pp 285306.

Wood, D.M. (1990) Soil behaviour and critical state soil mechanics. Cambridge, United Kingdom, Cambridge University Press, 462 pp. 


\begin{tabular}{|c|c|c|c|c|c|c|}
\hline & & Triaxial geometry & $\begin{array}{l}\text { Interface } \\
\text { geometry }\end{array}$ & $\begin{array}{l}\text { Shear } \\
\text { geometry }\end{array}$ & Full scale & Units \\
\hline \multirow{20}{*}{ 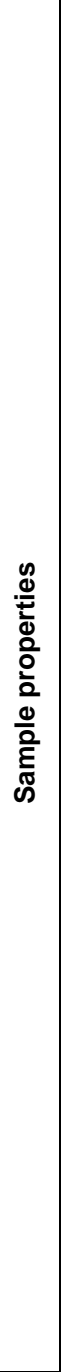 } & Sample reference & SPP_COx-2 & $\begin{array}{l}\text { ASR_Tau01 and } \\
\text { ASR_Tau12 }\end{array}$ & DSR_OPA-1 & Lasgit & \\
\hline & Material & $\begin{array}{l}\text { Callovo-Oxfordian } \\
\text { Claystone }\end{array}$ & Kaolinite & Opalinus Clay & Bentonite & \\
\hline & Location & Bure URL, France & $\begin{array}{l}\text { ECC quarry, St } \\
\text { Austell, UK }\end{array}$ & $\begin{array}{l}\text { Mont Terri URL, } \\
\text { Switzerland }\end{array}$ & $\begin{array}{l}\text { Äspö HRL, } \\
\text { Sweden }\end{array}$ & \\
\hline & $\begin{array}{l}\text { Borehole / drill } \\
\text { core }\end{array}$ & $\begin{array}{l}\text { OHZ1201/ } \\
\text { EST30341 }\end{array}$ & 1 & $\mathrm{BHA}-8$ & DA3147G01 & \\
\hline & Core direction & Parallel to bedding & I & $\begin{array}{l}\text { Perpendicular to } \\
\text { bedding }\end{array}$ & I & \\
\hline & Sample geometry & Cylindrical sample & Gouge material & Block sample & $\begin{array}{l}\text { Compacted } \\
\text { ring }\end{array}$ & \\
\hline & Average length & $82.45 \pm 0.03$ & $60.0 \pm 0.08$ & $20.61 \pm 0.04$ & $7,530 \pm 5$ & $\mathrm{~mm}$ \\
\hline & $\begin{array}{l}\text { Average diameter } \\
\text { / width }\end{array}$ & $55.85 \pm 0.04$ & $0.06-0.08$ & $59.62 \pm 0.14$ & $1,632 \pm 1$ & $\mathrm{~mm}$ \\
\hline & Volume & $2.020 \times 10^{-4}$ & $2.52 \times 10^{-7}$ & $1.471 \times 10^{-4}$ & 11.23 & $\mathrm{~m}^{3}$ \\
\hline & Average weight & 495.02 & 1 & 352.66 & $2.29 \times 10^{7}$ & g \\
\hline & Density & 2.451 & 1 & 2.397 & 2.056 & g.cc ${ }^{-1}$ \\
\hline & Grain density & 2.7 & 2.62 & 2.69 & 2.77 & g.cc ${ }^{-1}$ \\
\hline & Moisture weight & 28.7 & I & 20.45 & $4.43 \times 10^{6}$ & g \\
\hline & Moisture content & 6.2 & I & 5.8 & 24.0 & $\%$ \\
\hline & Dry weight & 466 & I & 332.21 & $1.85 \times 10^{7}$ & g \\
\hline & Dry density & 2.31 & 1 & 2.257 & 1.65 & g.cc ${ }^{-1}$ \\
\hline & Void ratio & 0.174 & I & 0.192 & 0.687 & \\
\hline & Porosity & 14.8 & I & 16.08 & 40.6 & $\%$ \\
\hline & $\begin{array}{l}\text { Degree of } \\
\text { saturation }\end{array}$ & 96 & I & 81.4 & 97.1 & $\%$ \\
\hline & $\begin{array}{c}\text { Gravimetric } \\
\text { water content }\end{array}$ & I & 80 & 1 & I & $\%$ \\
\hline \multirow{7}{*}{ 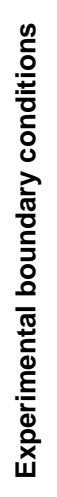 } & $\begin{array}{l}\text { Confining } \\
\text { pressure }\end{array}$ & 12.5 & I & I & In situ & $\mathrm{MPa}$ \\
\hline & Axial load & 13 & I & I & In situ & $\mathrm{MPa}$ \\
\hline & Pore pressure & $4.5-10.5$ & 0.75 and 5 & 1 & $1.5-6$ & $\mathrm{MPa}$ \\
\hline & Back pressure & 4.5 & Atmosphere & atmosphere & In situ & $\mathrm{MPa}$ \\
\hline & Normal load & I & $0.2-3-0.1$ & 1.2 & I & $\mathrm{MPa}$ \\
\hline & Shear rate & I & None & 85 & I & $\mu \mathrm{m} / \mathrm{day}$ \\
\hline & $\begin{array}{l}\text { Pore fluid } \\
\text { chemistry }\end{array}$ & $\begin{array}{l}\text { Chemically } \\
\text { balanced pore } \\
\text { fluid for Bure }\end{array}$ & $\begin{array}{l}\text { De-ionised water } \\
\text { / helium }\end{array}$ & $\begin{array}{l}\text { Chemically } \\
\text { balanced pore } \\
\text { fluid for Mont } \\
\text { Terri }^{\circledR}\end{array}$ & Water / neon & \\
\hline
\end{tabular}

Table 1 Description of pre-test material properties and experimental boundary conditions for the

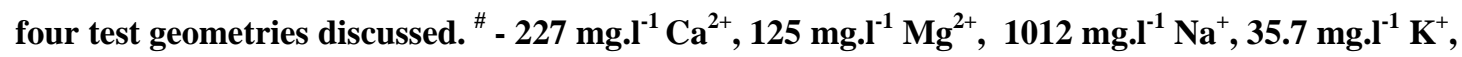
$1266 \mathrm{mg.l}^{-1} \mathrm{SO}_{4}{ }^{2-}, 4.59 \mathrm{mg.l}^{-1} \mathrm{Si}, 9.83 \mathrm{mg.l}^{-1} \mathrm{SiO}_{2}, 13.5 \mathrm{mg.l}^{-1} \mathrm{Sr}, 423 \mathrm{mg.l}^{-1}$ total S, and $0.941 \mathrm{mg.l}^{-}$

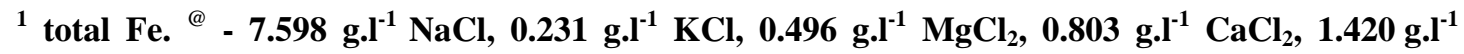
$\mathrm{Na}_{2} \mathrm{SO}_{4}$ and 0.033 g. ${ }^{-1} \mathrm{Na}_{2} \mathrm{CO}_{3}$ (Pearson et al., 1999). 

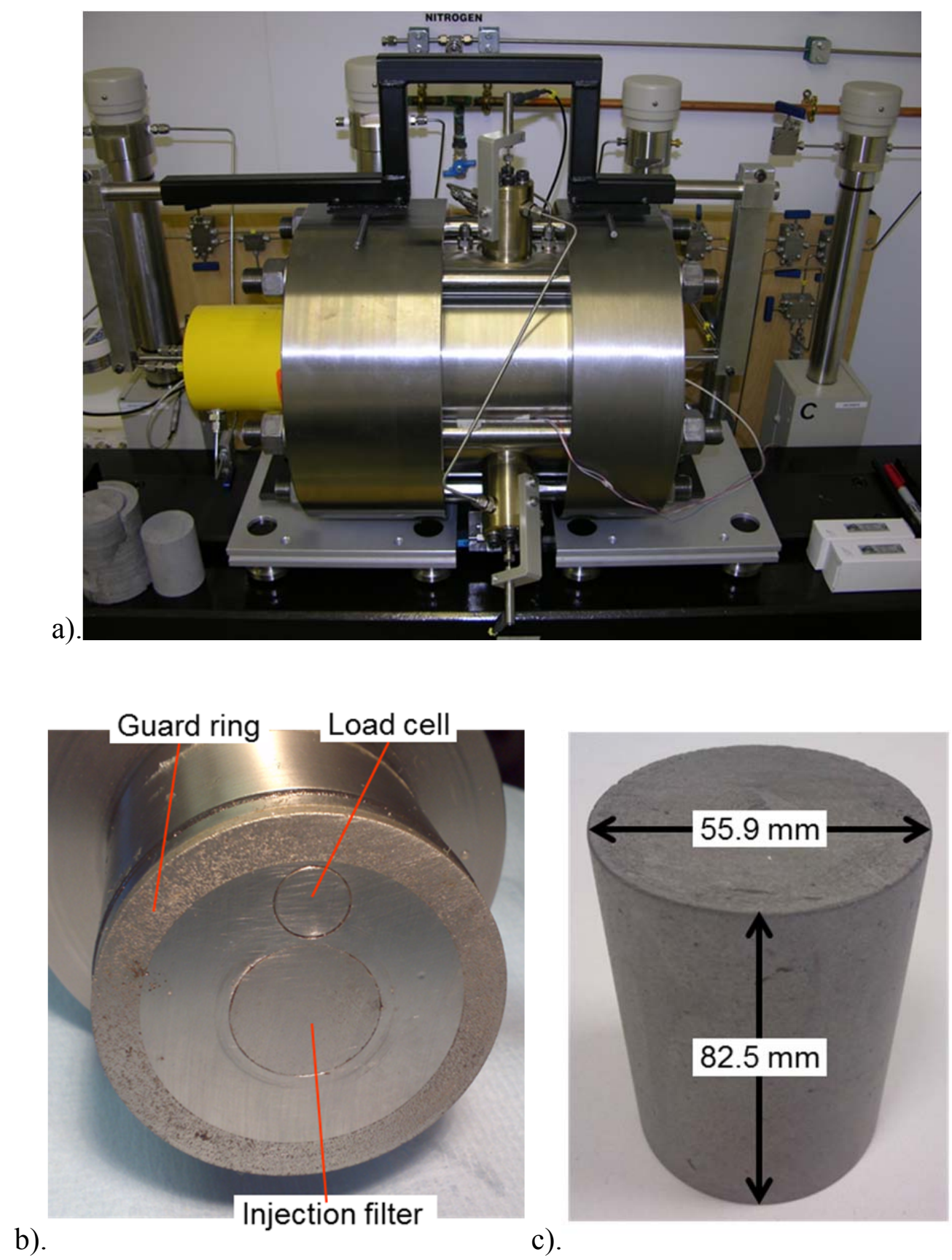

c).

Figure 1 - Triaxial test setup; a) triaxial Stress-Path Permeameter (SPP) apparatus, b) end platen showing the injection filter and guard ring arrangement, c) sample of Callovo-Oxfordian claystone prior to testing. 


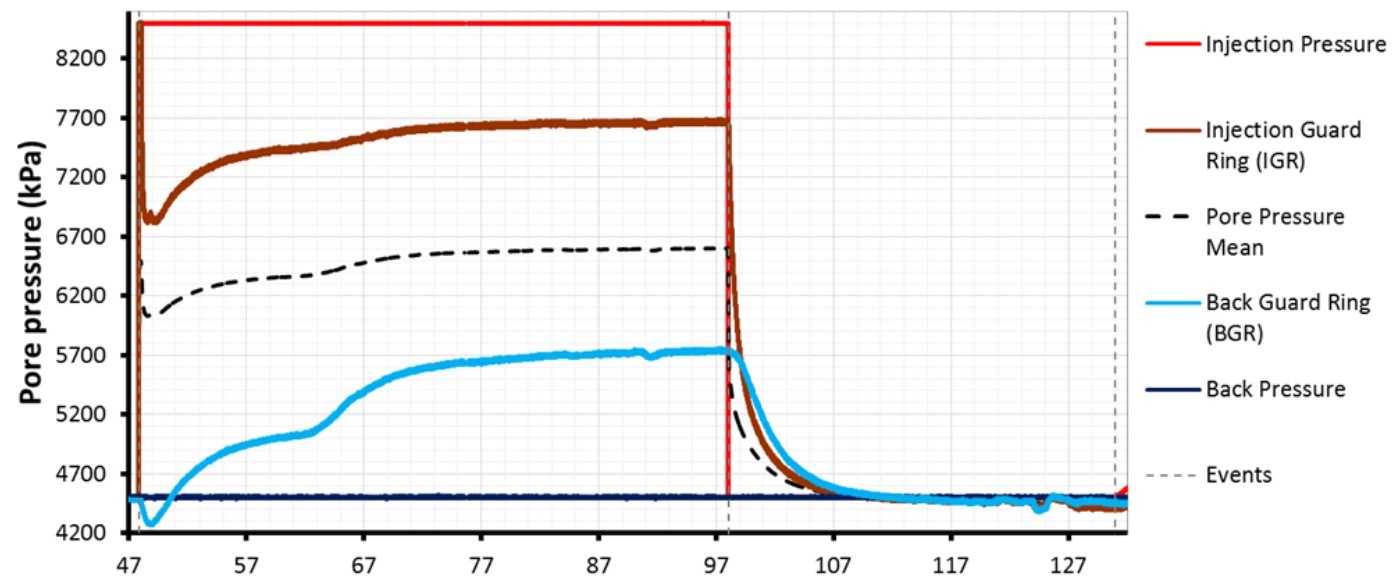

a).

Elapsed time (d)

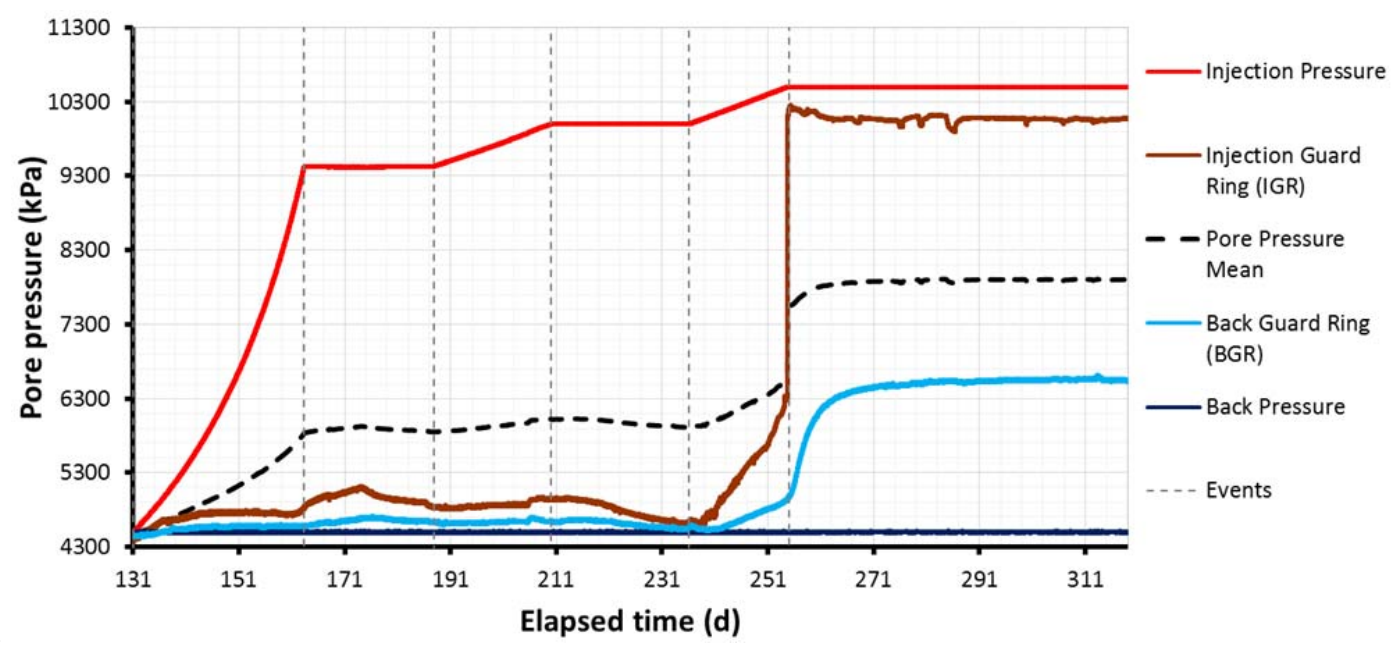

Figure 2 - Results of pore pressure recorded during hydraulic and gas testing of CallovoOxfordian claystone a) during water-injection testing, b) during gas injection. Differences can be clearly seen between the distribution of pore pressure within the sample during water and gas injection. 


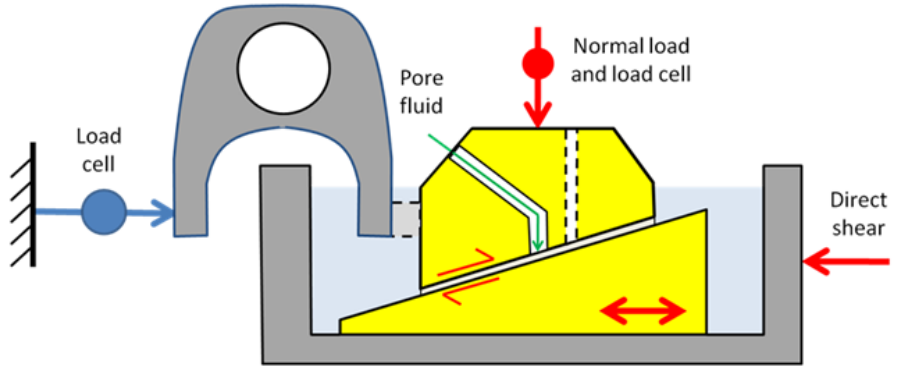

a).

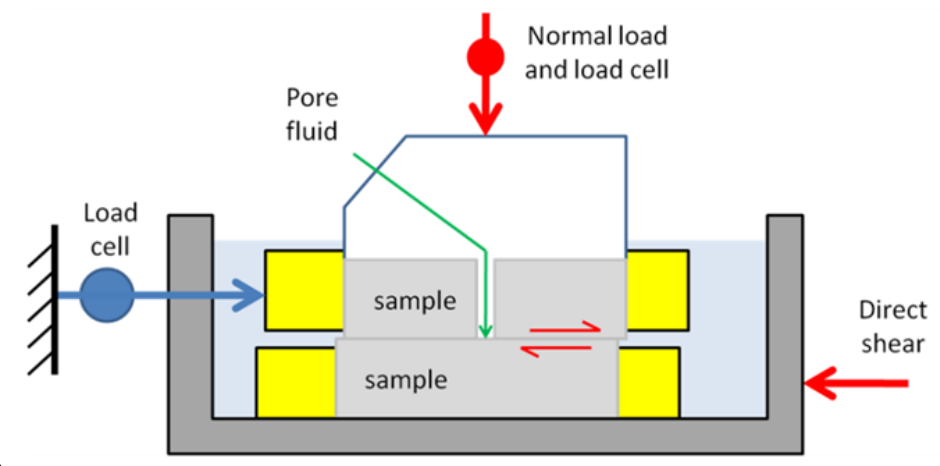

b).

Figure 3 - Schematic views of a) the Direct Shear Rig (DSR) and b) the Angled Shear Rig (ASR).

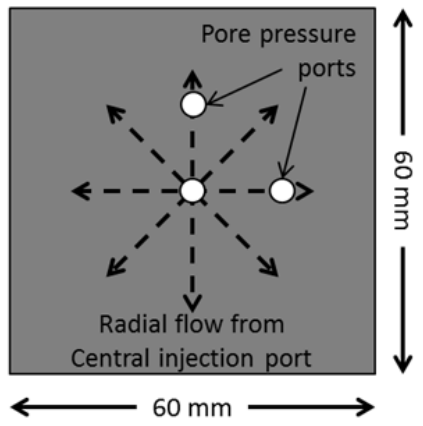

Plan view of slip-plane

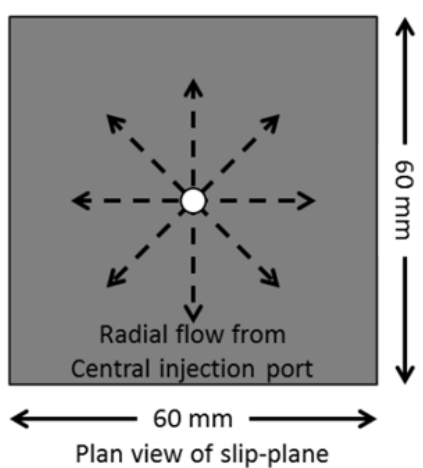

Plan view of slip-plane

\section{药

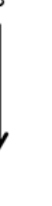

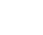



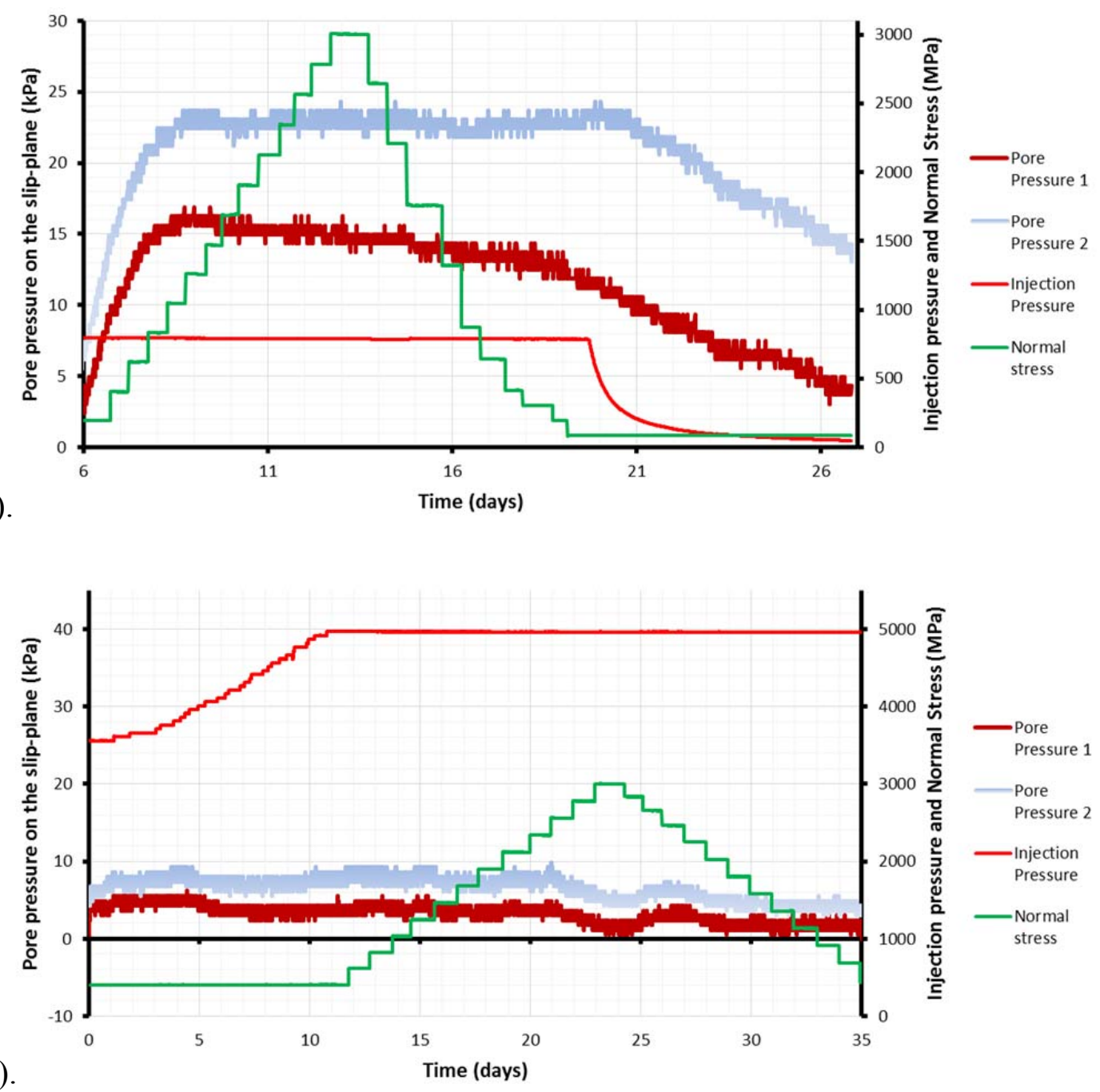

Figure 4 - Observations of pore pressure on the slip-plane during testing without active shear a) during water-injection testing, b) during gas injection. Relatively low pore pressures are observed within the slip-plane and the evolution of pore-pressure appears independent of the normal load on the slip-plane. 

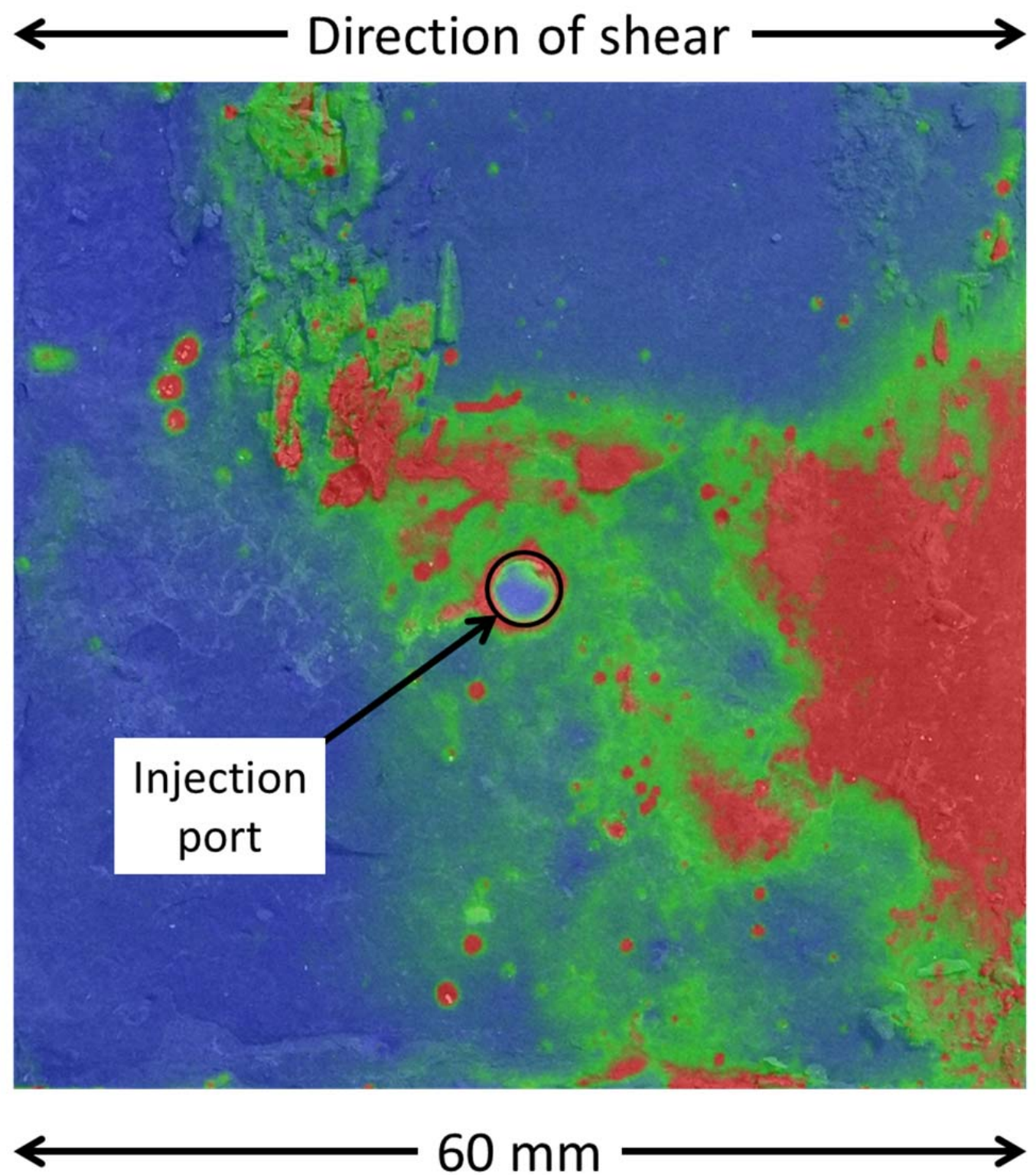

Figure 5 - Distribution of fluorescein staining during shear testing of Opalinus Clay. Laserstimulated scanning fluorescence image (LSSFI) under blue (450 $\mathrm{nm})$ excitation superimposed onto photomicrograph of the post-experiment contact surface of the upper clay block. The relative concentration of the fluorescein is indicated by the rainbow colour scale $[R E D=$ high concentration; BLUE = absent]. 

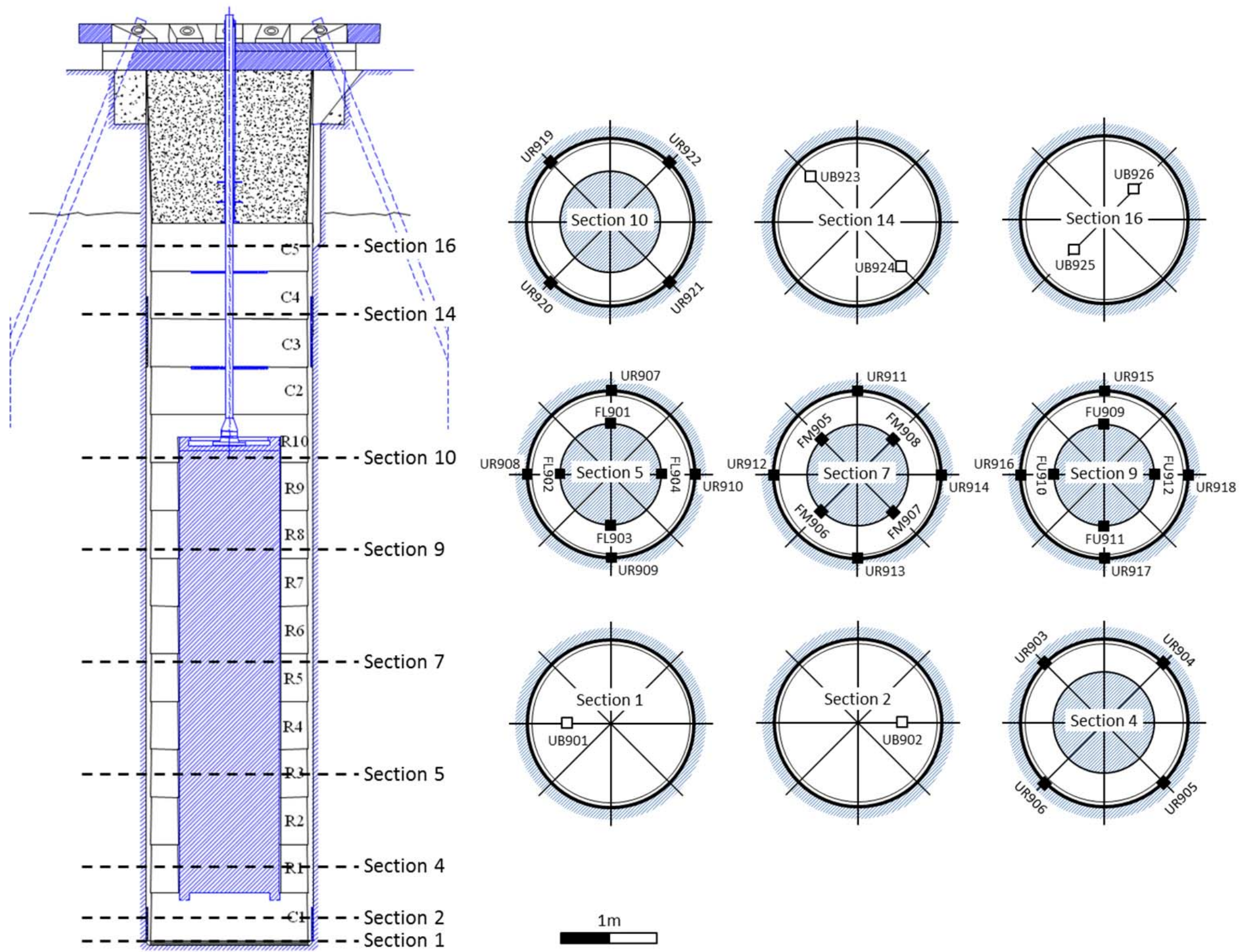

Figure 6 - Schematic of the layout of the Lasgit experiment showing the locations of sensors displayed in Figure 7 and Figure 8. 


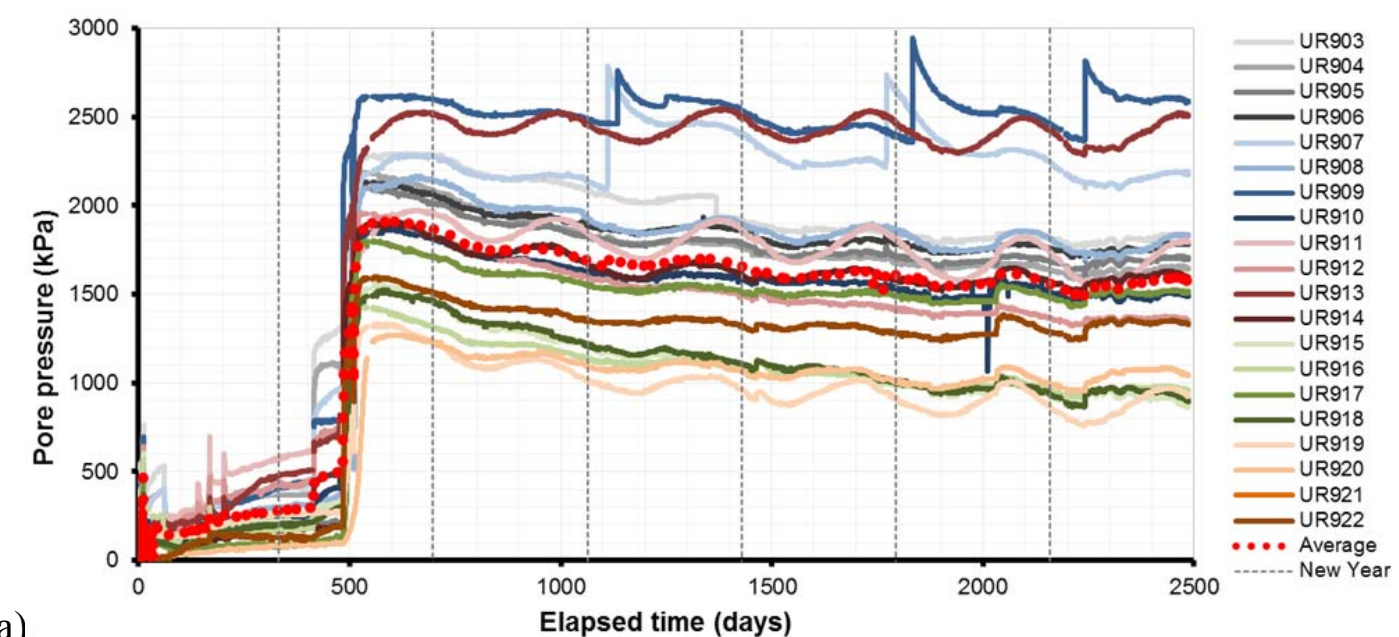

a)

Elapsed time (days)

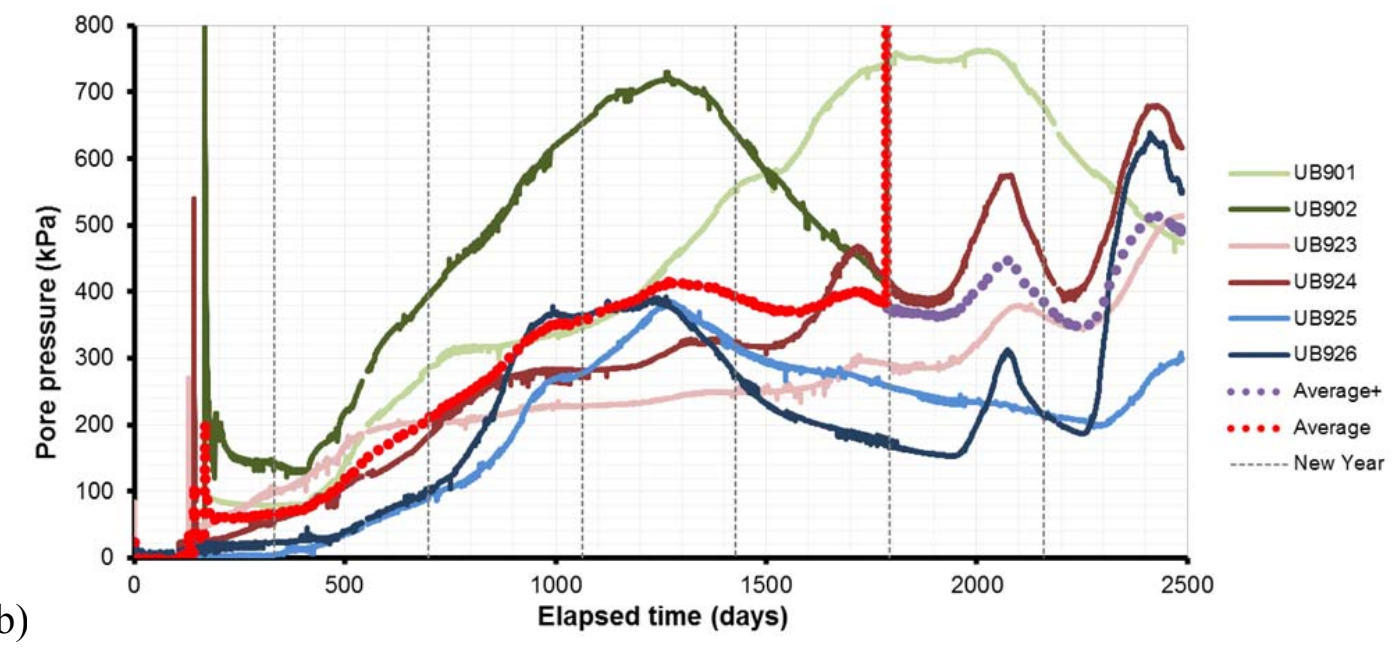

Figure 7 - Hydraulic pore-pressure seen in Lasgit a) at the rock wall, b) within the bentonite buffer. Pore pressure at the rock wall greatly increased around day $\mathbf{5 0 0}$ following the installation of a pressure-relief hole. Since this date the pressure has decayed due to changes in drawdown of the Äspö tunnel. Pore pressure within the bentonite is much more complex and has evolved to a magnitude much less than observed at the rock wall. 


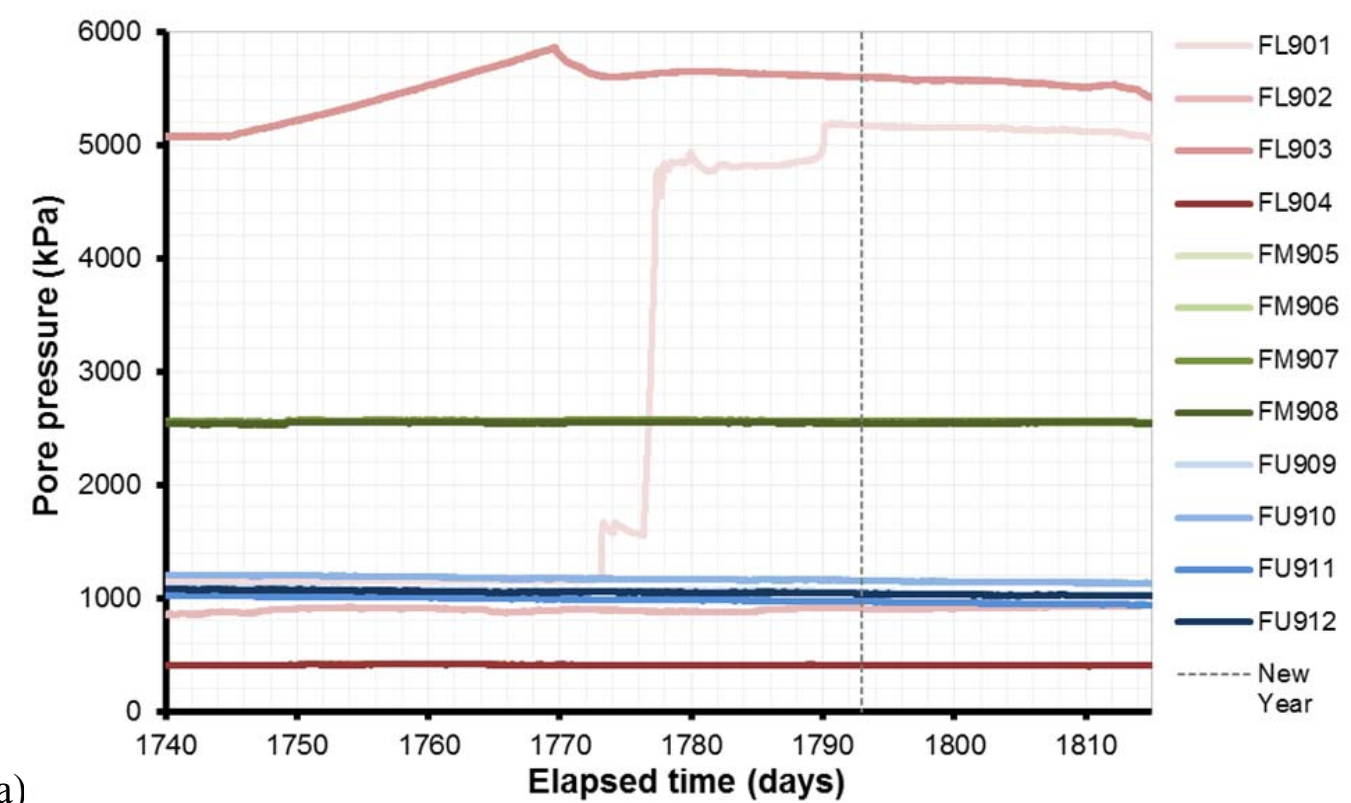

a)

Elapsed time (days)

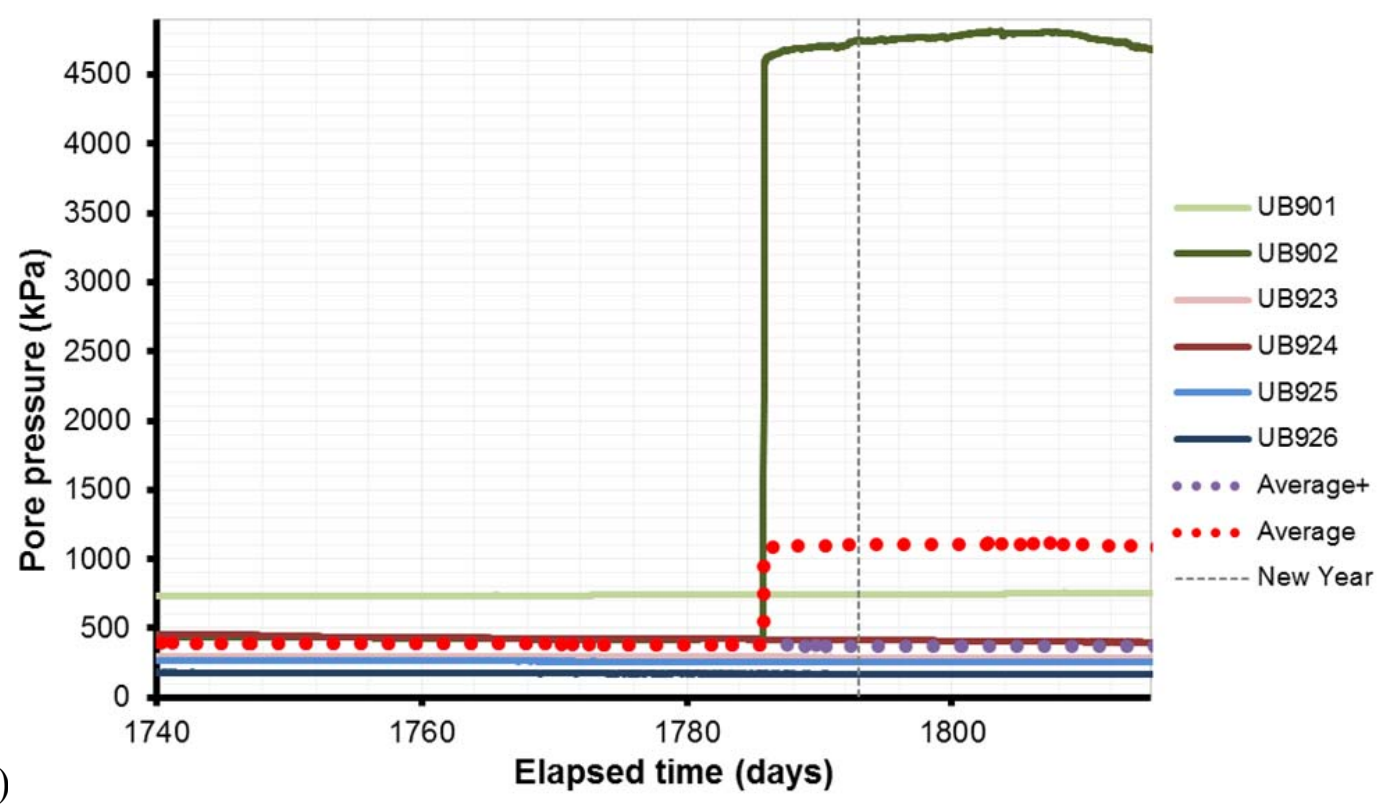

Figure 8 - Pore-pressure seen in Lasgit during gas testing a) in canister filters, b) within the bentonite buffer. Gas pressure was raised in filter FL903 until gas entry into the bentonite buffer. Pressure increases in filter FL902 and UB902 sometime after gas breakthrough illustrate the temporal migration of gas within Lasgit. 